\title{
Why Marx Was a Bad Driver: Alienation to Sensuality in the Anthropology of Automobility
}

\author{
Andrew Dawson \\ University of Melbourne, Melbourne, Australia \\ Email: dawsona@unimelb.edu.au
}

How to cite this paper: Dawson, A. (2017). Why Marx Was a Bad Driver: Alienation to Sensuality in the Anthropology of Automobility. Advances in Anthropology, 7, 1-16.

https://doi.org/10.4236/aa.2017.71001

Received: November 15, 2016

Accepted: November 22, 2016

Published: December 30, 2016

Copyright (C) 2017 by author and Scientific Research Publishing Inc.

This work is licensed under the Creative

Commons Attribution International

License (CC BY 4.0).

http://creativecommons.org/licenses/by/4.0/

\begin{abstract}
Contemporary automobilities research is characterised by a fundamental paradox-recognition of driving as a sensate experience alongside a tendency to emphasise the driver's sensory disengagement from, rather than engagement with the bodily, social and environmental contexts with which s/he interacts. In this article, which builds on previous empirical work I have published, only now in a more theoretical and comparative directions, I undertake three tasks. I locate automobilities researches' concern with the senses in its broader contexts of substantive enquiry-namely, the "Mobilities Paradigm" and the social scientific study of the "Senses". I posit the theoretical basis of the representation of sensory disengagement in driving in automobilities research, specifically in post-war Marxian thought and its critique of Capitalist Modernity and concern with alienation. Lastly, I review three anthropological case studies that represent sensory engagement in driving, one from Palestine, one from Turkey and my own from Bosnia and Herzegovina. I go on to suggest that the approach they share, which is indicative of a growing trend towards the anthropological study of automobilities, is valuable in two ways. It is a corrective to the inappropriate representation of sensory disengagement that is a characteristic of most automobilities research. Also, through its ability to convey sensory engagement in driving, I argue that it provides important insights on the contemporary nature of enduring, but now increasingly mobile social phenomena such as, as in these particular cases sectarian enclosure, class segregation, and ethnic-national transition.
\end{abstract}

\section{Keywords}

Mobility, Automobility, The Body, The Senses

\section{Introduction}

"When I think of my body and ask what it does to earn that name, two 
things stand out. It moves. It feels. In fact, it does both at the same time. It moves as it feels, and it feels itself moving. Can we think a body without this: an intrinsic connection between movement and sensation whereby each immediately summons the other?" (Massumi, 2002: p. 1)

Contemporary automobilities research is characterised by a fundamental paradox-recognition of driving as a sensate experience alongside a tendency to emphasise the driver's sensory disengagement from, rather than engagement with the bodily, social and environmental contexts with which s/he interacts (2015a). Thus, in answer to Brian Massumi's rhetorical question, yes a body can be thought without an intrinsic connection between movement and sensation, even though it should not. And, contemporary research on automobilities often represents an unexpected case of such failed thinking.

In an earlier publication I mention in passing this point about the representation of sensory disengagement in driving within automobilities research, on the way to developing a case-study empirical analysis of the engagement of the senses in driving and, in particular how they frame Bosnian people's conceptualisations of post-war transformation (2015a). Following its restatement, in this article I take my observation of the representation of sensory disengagement in driving within automobilities research in several new, and developmental directions. These are as follows:

(1) I locate automobilities researches' concern with the senses it in its broader contexts of substantive enquiry - namely, the "Mobilities Paradigm" and the social scientific study of the "Senses", offering a review of pertinent literature and contributing theories in the process.

(2) I posit the theoretical basis of the representation of sensory disengagement in driving in automobilities research. I argue that despite its theoretical eclecticism, automobilities research continues to be framed by the dispositions of post-war Marxian thought, which was the key genus of automobilities research in general. In particular, I argue that representation of sensory disengagement in driving derives from the Marxian critique of Capitalist Modernity, for which the motorcar is a key symbol. Furthermore, I argue, the representation of sensory disengagement in driving derives from the Marxian concern with alienation, of which sensory disengagement is one manifestation.

(3) Finally, I review three anthropological case studies that represent sensory engagement in driving, one from Palestine, one from Turkey and my own from Bosnia and Herzegovina. As well as offering these as a corrective to the inappropriate representation of sensory disengagement that is a characteristic of most automobilities research, I illuminate a particular value in these kinds of study for both the interdisciplinary field of automobilities studies and for Anthropology and the Social Sciences more broadly. In a world where heightened mobility is an increasingly ubiquitous experience, such case studies illustrate how attention to sensual engagement in a driving, a phenomenon almost uniquely available to anthropology through its distinctively intimate methodological modus operandi, can provide important insights on the contemporary nature of enduring, but 
now increasingly mobile social phenomena such as, in these cases sectarian enclosure (Palestine), class segregation (Turkey) and ethnic-national transition (Bosnia and Herzegovina).

\section{The Mobilities Paradigm and Automobilities Research}

The Mobilities Paradigm's coming into being was marked by two especially influential position papers (Hannam, Sheller, \& Urry, 2006; Sheller \& Urry, 2006). They highlight the primary motivation of the paradigm, a need for the social sciences to come to grips with globalization, especially the accelerating incidence and speed of the mobility of people and things enabled by new transportation and communication technologies. The Mobilities Paradigm has, since then come to occupy an important place in the social sciences. It is the subject of a series of major works (Cresswell, 2006), theoretical statements (Cresswell, 2010), collections (Binnie et al., 2007; Vannini, 2009; Fincham et al., 2010), reviews (Blunt, 2007; Vannini, 2010), textbooks (Adey, 2010) and, in the form of Mobilities, a dedicated journal.

The Mobilities Paradigm's roots (or “routes” (Clifford, 1997)) were disciplinarily diverse (Faulconbridge \& Hui, 2016). In general, early contributions from most key participating disciplines, especially Sociology and Cultural Geography, were "constructive". At one level there has been a re-framing of foundational concepts deployed by these disciplines in ways that take mobility into account. Thus, for example, society, culture and place have increasingly been supplanted by new mobile metaphors such as "network", "flow", "(de/re) territorialisation", etcetera (Dawson, 2015b). At another level, there has been a proliferation of empirical studies of virtually all forms of physical mobility, from airline (Adey, 2010) and helicopter (Cwerner, 2006) travel to train journeying (Lofgren, 2008) to car driving (Vannini, 2010) to motor-biking (Pinch \& Reimer, 2012) and to various kinds of leisure and sporting mobility such as skiing (Edensor \& Richards, 2007) and canoeing (Waskul \& Waskul, 2009) to name but a few.

Anthropology too has made its constructive contributions to the Mobilities Paradigm. Notably, it has provided significant empirical research on non-mechanised forms of mobility, especially walking (Ingold \& Vergunst, 2008). Furthermore, and more importantly, it has been at the forefront of the development of new mobile methodologies such as, most famously, multi-sited ethnography (Marcus, 1995). However, by and large, I argue, the early contribution of Anthropology to the study of mobilities was "deconstructive". It was, in essence, a bi-product of postmodern Anthropology's critique of methodological sedentarism (Clifford, 1997; Gupta \& Ferguson, 1997; Rapport \& Dawson, 1998). According to this, the discipline's central locus of research, "the field", was presented as a dubious trope of authority that also resonated with wider sedentarising ideologies such as nationalism (Clifford \& Marcus, 1986). Hence, the central drive of a mobilities anthropology was less to research mobilities per se than to demonstrate through deconstructive readings of anthropological monographs how and why anthropologists had often inappropriately rendered their research 
subjects immobile.

Nowhere does this constructive and deconstructive contrast between disciplines show through than in the paucity of anthropological research on car driving, unquestionably the predominant global form of mobility (Urry, 2006: p. 18). There is for sure a small body of anthropological research on the meaningfulness of cars, prime examples of which are Miller's volume within the Material Cultures tradition (2001) and Lipset and Handler's volume on the role of the car as a metaphor in culture, politics and history (Lipset \& Handler, 2014). Likewise, there is a small body of anthropological literature on the social relations between drivers/passengers and other drivers/passengers (Yazici, 2012), between drivers/passengers and the milieus they pass through (Klaeger, 2012), and between drivers/passengers and the "moorings" (Hannam, Sheller, \& Urry, 2006) that enable automobility, such as roads (Dalakoglou \& Harvey, 2012; 2016). To an even lesser extent, there is a very small body of anthropological literature on the interiority of the car-for example, the social relations between drivers and passengers, the non-driving behaviours of drivers (such as mobile working) and, the focus of this article, the emotions and feelings experienced whilst driving (Bishara, 2015; Dawson, 2015a; Yazıc1, 2013).

These deficits are particularly problematic in two key respects. Firstly, since more people are spending greater periods of their life within cars (Urry, 2006) it represents turning a blind eye to an increasingly ubiquitous phenomenon and definitive feature of the modern human condition. Secondly, anthropological ethnography is an unusually intimate mode of methodological engagement. Thus, the relative paucity of relevant anthropological research represents a unique, but missed opportunity on the part of our discipline to offer insight into the interior life of cars.

\section{Automobility and the Body}

The social scientific study of car driving coalesces around a few clear themes (Dawson, 2015a: p. 4). These are: the politics (Paterson, 2007) and governance (Merriman, 2006) of automobility; automobility's transformation of society (Latimer \& Munro, 2006), space (Czegledy, 2004; Huijbens, 2007) and temporality (Baudrillard, 1988; Bissell, 2007; Hutch, 2007; Neumann, 1993; Virillo, 1986, 1997), and what is commonly referred to as the automobility "system" (Bohm, 2006; Urry, 2004) - in its most influential iteration this is a path-dependent and self-reproducing system that, according to John Urry, the most influential scholar in the field, comprises six key components: the quintessential manufactured object (the car); the major item of individual consumption after housing, an extraordinarily powerful complex, the predominant form of "quasi-private" mobility, the dominant culture that sustains major discourses of what constitutes the good life; and the single most important cause of environmental resource-use (Urry, 2004, pp. 25-26). However, more so than any of the above, the issue of the body in driving dominates automobility literature.

There are three clear themes within contemporary research on the driver's 
body (Dawson, 2015a: p. 4). These are influenced by different, though sometimes overlapping theoretical traditions. One is concerned with the regulations and interventions designed to optimize drivers' bodily capacities to move safely and efficiently. Work on this theme is influenced, largely by Foucault's writing on knowledge, governmentality and bodily discipline (Bonham, 2006; Merriman, 2006).

Another theme is that of "habituation" (Dawson, 2015a: p. 4) -as Sheller puts it, the knowledge integral to driving that is, "precognitive and sensate rather than ideational" (Sheller, 2007: p. 180). One strand of this work is social constructionist and, commonly Foucaultian. A good illustrative example is Edensor and Holloway's work that demonstrates how the bodily rhythms of individuals are conditioned significantly by broader social rhythms of travel (including car travel) (Edensor \& Holloway, 2008). Another strand considers how the body in driving is socially constitutive, and is clearly influenced by Merleau-Pontyian phenomenology. A good illustrative example is Latimer and Munro's striking demonstration of how (precognitive) driving practices such as "changing gear", "cutting in" and "overtaking" permeate and instantiate broader cultural values and discursive formations (Latimer \& Munro, 2006: p. 49).

A final theme is that of "assemblages" (Dawson, 2015a: p. 4). Work on this theme is, by and large a response to automobile technological innovations and their destabilising the boundaries between drivers, cars and broader automobility systems, encompassing roads and other traffic technologies. One strand of this work focuses on the car/system nexus and their intertwining, especially through technologies such as Intelligent Transport Systems (ITS) (Beckmann, 2004). Though informed often by the kind of Foucaultian approach mentioned above, the car/system nexus literature draws most significantly on the actor-network theory of Bruno Latour (1996). Another strand focuses on the car/driver nexus, and their intertwining, especially through new in-car computing technologies. These are seen to have engendered new hybrid ontologies (Katz, 2000) that have been labelled variously as "humanized car(s)" (Katz, 2000) and "car-driver(s)" (Sheller \& Urry, 2000), or "driver-car(s)" (Dant, 2004) and "automobilized person(s)" (Katz, 2000: p. 33), or, expressing a perfect symbiosis of technical-human agency, "human-car co-agents" (Michael, 2000: 73) and "carson(s)" (Merriman, 2006: p. 75). Though informed often by the kind of phenomenological perspective mentioned above, this car/driver nexus literature draws most extensively on the hybridity (cyborg) theory of Donna Haraway (1991). The salient debate in the assemblages literature concerns the question of agency. In short, to which nexus may agency in driving be primarily attributed? For example, simultaneously hedging her bets whilst pinning her colours firmly to the car/system nexus, Sheller states: "If human bodies are being transformed by new technologies that seek to hybridize and effectively share agency, then the most significant and rapid transformations are taking place not at the scale of the individual body-in-the-car but at the level of the driver-car-software hybrid's interaction with systems of pervasive and embedded computing, surveillance 
and code-sorting that are automating, re-shaping and displacing to multiple scales and actants the wider movement-space of automobility" (Sheller, 2007: p. 177). Of course, given that the very point of this literature has been to unsettle boundaries, attributing agency to one nexus or the other is contradictory. Hence, after considerable debate (Dant, 2004), the explicitly Deleuzian term assemblages emerged. It conveys the mutualism of drivers, cars and systems.

Though apparently disparate, it is worth reminding ourselves that these concerns with discipline, assemblage and habituation emerge from a shared focus on embodiment. In turn, this necessarily makes for another shared concern with the sensual dimensions of driving.

\section{Automobility and the Senses}

One of the more marked trends across the social sciences in recent years has been growing interest in the senses (Stoller, 1989; Howes, 1991, 2005; Geurts, 2005; Pink, 2009). While, undoubtedly, primary attention has been accorded to sight (Urry \& Larsen, 1990), there are many studies of the roles of the other Euro-American "classic" senses of sound, smell, taste and touch. Furthermore, critiques of traditional research in which different senses were treated as discreet biological pathways that respond independently to physical stimuli are being superseded by an appreciation of the senses as an interconnected web of perceptory apparatuses (Potter, 2008). A key sensory constellation, or, as Geurts terms it, generalized "feeling of the body" (Geurts, 2005: p. 2) considered in mobilities research is, of course, kinaesthesia (Massumi, 2002).

This more general interest in the senses is reflected in the automobilities literature. For example, in a Classic early statement of an increasingly common type, Idhe wonders at the sensory impacts of newly emergent techno-human hybrid assemblages in driving. He states, "the expert driver when parallel parking needs very little by way of visual clues to back himself into the small place he 'feels' the very extension of himself through the car as the car becomes a symbiotic extension of his own embodidness" (Idhe, 1974: p. 272).

Despite such wonderment, treatment of the senses in driving in the automobilities literature has been disappointingly narrow and skewed. In short, there have been very few empirical investigations of the senses in driving. Furthermore, those few studies tend to focus on sensory "disengagement" rather than “engagement" (Dawson, 2015a: p. 4). I develop further this point below, and go on to speculate why this situation has come to pass. In particular, I suggest that, despite automobilities researches' theoretical eclecticism, it is constrained by its early roots in post-war Marxiam scholarship that views car culture as a quintessential manifestation of Capitalist Modernity and, thus, an object for critical scrutiny more than for sympathetic understanding.

How is driving represented as a sensually disengaging experience? Firstly, despite conceptualization of the senses as an interconnected web of perceptory apparatuses, a commonplace representation in automobilities studies is that car driving involves disengagement of the senses from one another (Dawson, 2015a: 
p. 6). For example, Urry describes the driver's body as being, "fragmented and disciplined to the machine, with eyes, ears, hands, and feet, all trained to respond instantaneously and consistently" (Urry, 2006: p. 23). Furthermore, hierarchical ranking of the senses is commonplace. Driving is seen as involving a privileging of vision over other senses. Such ocular-centrism (Fabian, 1984) is presented as being part of a broader process in which the world is sensed increasingly through the screen (Morse, 1998), the windscreen in this case (Baudrillard, 1988).

Secondly, despite the centrality of the Merleau-Pontyian phenomenological perspective in which it is asserted that driving knowledge is precognitive and sensate rather than ideational, a commonplace representation in the automobilities literature is that driving involves a disengagement of bodies from minds (Dawson, 2015a: p. 8). And, just as intellection in driving is represented often as heightened-an opportunity for detached contemplation as one daydreams down motorways for example (Pearce, 2000)-sensation is often represented as repressed. The work of French cultural theorist of speed, Paul Virillo (1986), is usually key in this respect. Virillio-inspired scholars represent the speed of driving as, variously, "overwhelming” (Árnason, Baldur Hafsteinsson, \& Grétarsdóttir, 2007), "bewildering" (Cubitt, 2000) or "alienating the human body sensorium" (Kellner, 2000: p. 105). In another vein, others point to the irony of a technology that simultaneously enables the driver's rapid bodily movement through space, whilst constraining it within the confines of the car. As Urry describes, although, "automobility is a system of mobility par excellance it necessitates the minimum of movement once one is strapped into the driving seat". And, he continues, "the car is a room in which the senses are necessarily impoverished” (Urry, 2006: p. 23). Indeed, according to Massumi’s logic (2002), a body without movement-such as the [s]trapped-in driver's body-is a body without sensation.

Thirdly, there is an emphasis in the automobilities literature on sensory disengagement between the car driver and the social world (Dawson, 2015a: p. 12). The best-known example of this is Urry's Simmelian analysis. He states, rather poetically that, "roads are simply full of moving, dangerous iron cages", such that, "there is no reciprocity of the eye and no look is returned from the ghost in the machine" (Urry, 2006: p. 22). Simmel's point was that the purest form of inter-personal communication comes through looking into one anothers' eyes, a possibility that, according to Urry, is diminished by the act of driving.

Finally, there is an emphasis in automobilities literature on sensory disengagement between the car driver and the environment broadly (Dawson, 2015a: p. 13). In this respect the car is frequently represented as a kind of cocoon that, variously enables the mobile reproduction of erstwhile static private domestic (Laurier et al., 2008), occupational (Laurier, 2004) and, of course, sensory spaces. Within the latter the driver is comforted by familiar sounds (Bull, 2004), and protected from the unwelcoming temperatures, smells and sounds of the outside world (Butler \& Hannam, 2014). Furthermore, and especially because of the de- 
velopment of safety technologies such as airbags, crumple-zones, all-wheel drive, distance sensors and connected ABS breaking systems, the car is represented increasingly as a barrier against the dangers of the road (Pinch \& Reimer, 2012). Again, the senses are seen as involved in this, and often in opposing ways. For example, writing from within the assemblages perspective, Dant sees the hybridization of the driver and car as the basis for that driver's feeling of protection, as the car's bodywork is felt increasingly as being a kind of exoskeletan (Dant, 2004). In contrast, for some others the dissembled person and car is the basis for the feeling of protection. Pinch and Reimer, for example, highlight how the motorcyclist experiences an intense exposure and risk that is the very basis for her acute sensory engagement with the materialities of both the machine and the road (Pinch \& Reimer, 2012). They contrast this with the modern car, whose new technologies-such as advanced suspension systems which, pleasingly enable increasingly smooth drives-sensually disengage the driver from the broader environment. Consequently, the driver experiences increasingly, perhaps unwarranted feelings of safety.

Why is there an emphasis on sensory disengagement in automobilities research? Leading mobilities scholar Tim Cresswell offers some clues. He highlights a critical disjuncture between the representation of mechanized and non-mechanised forms of mobility. He observes, for example, that, "walking is wrapped up in narratives of worthiness, morality, and aesthetics that constantly contrast it with more mechanised forms of movement which are represented as less authentic, less worthy, less ethical" (Cresswell, 2010: p. 20). Negative representation of car driving is especially acute. Driving has, apparently, deleterious impacts on the environment (Jain \& Guiver, 2001), health (Freund \& Martin, 2007) and society (Fotsch, 2007). It overwhelms and marginalizes other and more benign modes of transport (Horton et al., 2007). It destabilizes global political economies (Paterson, 2007). Indeed, as Mimi Sheller hints, through its gargantuan consumption of oil and other raw materials such as aluminium, it is even plausible to argue that automobility lies at the root of many contemporary resource-based global conflicts (Sheller, 2015). Driving as a sensually disengaged experience may, perhaps, be added to this long list of its many supposed woes.

A good deal of this negative representation is reasonably grounded of course. Nonetheless, the absence of research highlighting the many benefits of car driving, such as its role as an especially safe method of travelling for vulnerable groups such as women and ethnic minorities, is conspicuous by its absence. This practice of intellectual car bashing suggests, I would argue, and not at all conspiratorially, deeper agendas lurking within contemporary automobilities research. Principal amongst these is, I suggest, critique of Capitalist Modernity, whose quintessential productive form is, after all, Fordism.

The resonances between earlier Marxian and later theoretically eclectic automobilities research are remarkable and replete. However, for the purposes of understanding the senses in automobility it is a shared concern with issues of selfhood that is especially important. The "auto" in automobility is multivocal, 
speaking simultaneously of the mechanical capacity for movement (as is "automaton"), reflexive selfhood (as in "autobiographical") and, closely associated with this, individuality (the "autonomous self") (Urry, 2006: p. 18). This latter sense of automobility was of special interest for Marxian scholars in the post-war era, such as Henri Lefebvre, for whom the motorcar industry was a key symbol of the Americanisation of Europe (Bosquet, 1977). Automobility was a symbol of freedom-celebrated most famously in the genre of the road novel, movie and song. However, by the Marxists this freedom was seen as intrinsically functional for the interests of capital, an expression of a bourgeois individualism (Boltanski, 1975) primed for the development of an increasingly privatized consumer society (Gilroy, 2001: p. 89). In turn, the apparent "freedom" of automobility was also seen by the Marxists as intrinsically illusory, ideologically disguising processes of control (Gorz, 1973).

The Marxists' concern with illusory autonomy and control in automobility is conveyed most eloquently by Lefebvre in his seminal automobilities work on the Parisian suburb, that form of conurbation which, almost uniquely amongst others, was designed with the motorcar in mind. He states, driving "enables people... to congregate and mix without meeting, thus constituting a striking example of simultaneity without exchange" (Lefebvre, 1971 (1968)). However, in fact, the concern that Lefebvre expresses is clearly reflected in all theoretical traditions in new automobilities research. In Bohm's influential Foucaultian analysis of automobility and embodiment, for example, automobility is fundamentally oxymoronic. Never truly "auto", automobility is always dependent upon external interventions, such as the provision of special technologies and places to render it possible (Bohm, 2006: p. 11). Likewise, in his equally influential Latourian analysis of ITS and the system/car/driver's body nexus, Beckmann states, "every new implant seems to dislocate the driver from the problematic 'traffic community' and enhances autonomy... however, this autonomy and independence is fictitious. The more human and non-human agents enter the roads, the tighter the actor-network is woven" (Beckmann, 2004: p. 89). More surprisingly perhaps, the concern is reflected even in phenomenological research on automobility and embodiment. For example, in an especially insightful analysis Latimer and Munro argue that automobilility has engendered a new kind of being-in-the-world in which choosing to pursue lifestyles that are relatively slow, stationary or static is rendered illegitimate (Latimer \& Munro, 2006: p. 49). Indeed, speaking of the dubious benefits of being freed from the spatial constraints and modernist time of public transport systems, Urry argues that car ownership brings with it a growing expectation to be in more places within ever-shorter time frames. As he puts it, automobility, "coerces people (and their bodies) into an intense flexibility" (Urry, 2006: p. 19). In short, whatever the theoretical persuasion, the story remains the same. Automobility is not auto at all. It's a case of control, control and more control.

Most importantly, the concern with control also, of course, resonates with the Marxian concept of alienation-a process in which people are increasingly 
dominated by the forces of their own creation, which confront them as alien powers. Implicit in the concept of alienation is the idea of estrangement, from ourselves, from others (our species being, as Marx termed it) and from the material environments we inhabit. And this is where I offer my answer to the question, "why is there an emphasis on sensory disengagement in automobilities research?" Through its prevailing concern with embodiment and reflecting its Marxian genus, contemporary automobilities literature renders alienation as sensory disengagement.

\section{Anthropological Approaches to the Senses in Driving}

Having illuminated representation of the sensually disengaged driver that predominates in automobilities research, by way of an optimistic conclusion I identify an emerging trend of new anthropological studies that take seriously and describe sensory engagement in driving. I summarise briefly three illustrative cases.

National Closure-In her outstanding article, "Driving while Palestinian in Israel and the West Bank: The Politics of Disorientation and the Routes of Subaltern Knowledge" (2015), Amahl Bishara considers the forms of political knowledge that Palestinians living in a context of divided residence between Israel and the West Bank obtain through the practice of driving. Driving is a means by which Palestinians experience and understand how occupation works. Through driving they encounter how Israeli settlement expansion functions to preclude Palestinian statehood through its disruption of the contiguity of Palestinian territory. Moreover, by witnessing roadblocks and other forms of traffic policing they encounter first hand the Israeli state's control of the Palestinian population. Against this, encounters the driver has with other Palestinians of different classes and from different places become a basis for a practiced rather than imagined pan-Palestinian national solidarity. And, finally, building on Brian Larkin's observation that infrastructures are key sites through which ordinary people encounter states and their idealized representations of the World (Larkin, 2013), Bishara demonstrates how through their tricky driving manoeuvres Palestinians "test out" their relationships with the Israeli state and, she implies, subvert its methods of control. Importantly, as Bishara also demonstrates, the political knowledge obtained through driving is particularly "affective". Why so? Because, in contrast to the sensually disengaged perspective on driving in the automobilities literature, driving is what Marcel Mauss (1973) describes as a "technique of the body". Concomitantly, political knowledge obtained through driving is especially embodied and sensate. For example, Bishara demonstrates how Israeli state control through traffic regulation and road closure is experienced as "disorientation". Likewise, she demonstrates how automobile manoeuvres such as U-turns to avoid checkpoints and the like are, and are experienced as acts of bodily resistance. By means of a focus on driving, Bishara develops an analysis of the everyday politics of the state that stands askance to commonplace liberal traditions in which political knowledge is idealized as abstract and dis- 
embodied. Political knowledge obtained through driving is, she demonstrates, intrinsically concrete and embodied and, thereby, sensorial.

Class Segregation-Berna Yazici's (2013) article, “Towards an Anthropology of Traffic: a Ride Through Class Hierarchies on Istanbul's Roadways", is, likewise, concerned with a kind of closure, in this case with the increasing class-based residential segregation of the neoliberal city. In these contexts, Yazici demonstrates, driving in ubiquitous traffic congestion is, less a means by which class divisions are transcended, and more a way in which they are brought into sharper relief. Furthermore, importantly, awareness of such divisions through driving is especially affective because it is visceral... sensual. Through driving, Yazici demonstrates, one becomes "acutely" aware of class divisions in ways that are "personal", "uncomfortable" and, indeed, even "embodied", as one witnesses, for example, the contrasts between the relaxing experience enjoyed by higher classes of driving in luxurious cars and the discomforting experience faced by lower classes who are forced to struggle for both space in crowded buses, and for breath in comparatively high-polluting vehicles.

Nationalism and Transition-In the article, "Driven to Sanity: an Ethnographic Critique of the Senses in Automobilities" (2015a), I explore the roles of sensory engagement in driving in ameliorating feelings of unease experienced by ordinary people in the newly independent post-war Bosnia and Herzegovina. I demonstrate, for example, how through the forms of skilled bodily coordination required to undertake it successfully driving affords people a sense of invigorated bodily integrity and ownership at a time when ethnic nationalism is calling into question, through proscription of fertility rights and the like, people's abilities to assume control of their own bodies. I demonstrate how the conduct of driving and the organisation of traffic according to pre-cognate pan-ethnic rules of the road afford drivers a sensate experience of Yugoslav communality that is otherwise undermined by the rise of ethnic nationalism. Finally, I demonstrate how driving provides a safe context for sensory engagement with an environment that has been substantially and often fearfully transformed from familiar pan-Yugoslav into unfamiliar ethnic national. Overall, I conclude, driving affords citizens a key sensory means of coming to terms with discomforting feelings of, respectively, losses of autonomy, losses of communality, and estrangement that are engendered by the rise of ethnic nationalism in Bosnia.

\section{Conclusion}

Building from earlier empirical work (2015a), this article has taken an observation about the representation of sensory disengagement in driving within automobilities research in several new, and developmental directions. To reiterate: Firstly, I have located automobilities researches' concern with the senses it in its broader contexts of substantive enquiry—namely, the "Mobilities Paradigm" and the social scientific study of the "Senses", offering a review of pertinent literature and contributing theories in the process. Secondly, I have posited the theoretical basis of the representation of sensory disengagement in driving in automobilities 
research. I have argued that despite its theoretical eclecticism, automobilities research continues to be framed by the dispositions of post-war Marxian thought, which was the key genus of automobilities research in general. In particular, I have argued that representation of sensory disengagement in driving derives from the Marxian critique of Capitalist Modernity and a concern with alienation, of which sensory disengagement is one manifestation. Finally, I have reviewed three anthropological case studies that represent sensory engagement in driving, one from Palestine, one from Turkey and my own from Bosnia and Herzegovina. These anthropological contributions are fruits of a shared methodology that I describe in detail elsewhere and label as "passenger-seat ethnography (Dawson, 2015c)". This enables an intimacy not usually amenable to other methodologies more typically employed by the other disciplines that dominate in the field of automobilities studies. And, I would suggest, this intimacy is a precondition for adequately appreciating and capturing the sensorial engagement of drivers. However, more that offering a corrective to the inappropriate representation of sensory disengagement that is a characteristic of most automobilities research, studies like these offer a broader value for automobilities studies, Anthropology and the social sciences more generally. In a world where heightened mobility is an increasingly ubiquitous experience, they illustrate how attention to sensuality in driving, a phenomenon almost uniquely available to anthropology through its distinctively intimate methodological modus operandi, can provide important insights on the contemporary nature of enduring, but now increasingly mobile social phenomena such as, in these cases sectarian enclosure, class segregation and ethnic-national transition.

\section{References}

Adey, P. (2010). Aerial Life: Spaces, Mobilities, Affects. Oxford: Blackwell Publishing. https://doi.org/10.1002/9781444324631

Adey, P. (2010). Mobility. London and New York: Routledge.

Árnason, A., Baldur Hafsteinsson, S., \& Grétarsdóttir, T. (2007). Acceleration Nation: An Investigation into the Violence of Speed and the Uses of Accidents in Iceland. Culture, Theory and Critique, 48, 199-217. https://doi.org/10.1080/14735780701723314

Baudrillard, J. (1988). America. London: Verso.

Beckmann, J. (2004). Mobility and Safety. Theory, Culture and Society, 21, 81-100. https://doi.org/10.1177/0263276404046062

Binnie, J., Edensor, T., Holloway, J., Millington, S., \&Young, C. (Eds.) (2007). Special Issue: Mundane Mobilities, Banal Travels. Social and Cultural Geography, 8, 165-174. https://doi.org/10.1080/14649360701360048

Bishara, A. (2015). Driving While Palestinian in Israel and the West Bank: The Politics of Disorientation and the Routes of a Subaltern Knowledge. American Ethnologist, 42, 33-54. https://doi.org/10.1111/amet.12114

Bissell, D. (2007). Animating Suspension: Waiting for Mobilities. Mobilities, 2, 277-298. https://doi.org/10.1080/17450100701381581

Blunt, A. (2007). Cultural Geographies of Migration: Mobility, Transnationality and Diaspora. Progress in Human Geography, 31, 684-694.

https://doi.org/10.1177/0309132507078945 
Bohm, S., Campbell, J., Land, C., \& Paterson, M. (Eds.) (2006). Part One: Conceptualizing Automobility: Introduction: Impossibilities of Automobility. Sociological Review, 54, $1-16$.

Boltanski, L. (1975). Accidents d'Automobile et Lutte de Classes. Actes de la Recherche en Sciences Sociales, 1, 25-49. https://doi.org/10.3406/arss.1975.2456

Bonham, J. (2006). Transport: Disciplining the Body That Travels. Sociological Review, 54, 57-74.

Bosquet, M. (1977). Capitalism in Crisis and Everyday Life. Howe, J., Trans., Hassocks: The Harvester Press.

Bull, M. (2004). Automobility and the Power of Sound. Theory Culture Society, 21, 243-259. https://doi.org/10.1177/0263276404046069

Butler, G., \& Hannam, K. (2014). Performing Expatriate Mobilities in Kuala Lumpur. Mobilities, 9, 1-20. https://doi.org/10.1080/17450101.2013.784530

Clifford, J. (1997). Routes: Travel and Translation in the Late Twentieth Century. London: Harvard University Press.

Clifford, J., \& Marcus, G. (1986). Writing Culture: The Poetics and Politics of Ethnography. Berkeley, CA: University of California Press.

Cresswell, T. (2006). On the Move: Mobility in the Western World. New York, NY: Routledge.

Cresswell, T. (2010). Towards a Politics of Mobility. Environment and Planning D: Society and Space, 28, 17-31. https://doi.org/10.1068/d11407

Cubitt, S. (2000). Virilio and New Media. In J. Armitage (Ed.), Paul Virilio: from Modernism to Hypermodernism and Beyond (pp. 127-142). London: Sage Publishers. https://doi.org/10.4135/9781446218242.n7

Cwerner, S. B. (2006). Vertical Flight and Urban Mobilties: The Reality of Helicopter Travel. Mobilities, 1, 191-215. https://doi.org/10.1080/17450100600726589

Czegledy, A. P. (2004). Getting around Town: Transportation and the Built Environment in Post-Apartheid South Africa. City and Society, 16, 63-92. https://doi.org/10.1525/city.2004.16.2.63

Dalakoglou, D., \& Harvey, P. (2016). Roads and Anthropology: Ethnography, Infrastructures, (Im)Mobility. London and New York, NY: Routledge.

Dalakoglou, D., \& P. Harvey. (2012). Special Issue: Roads and Anthropology: Ethnographic Perspectives on Space, Time and (Im)Mobility. Mobilities, 7, 459-465. https://doi.org/10.1080/17450101.2012.718426

Dant, T. (2004). The Driver Car. Theory, Culture and Society, 21, 61-79. https://doi.org/10.1177/0263276404046061

Dawson, A. (2015a). Driven to Sanity: An Ethnographic Critique of the Senses in Automobilities. The Australian Journal of Anthropology, 1-18.

Dawson, A. (2015b). Mobility's Turns. Social Anthropology/Anthropologie Sociale, 23, 330-364.

Dawson, A. (2015c) The Road to Srebrenica: Automobility and Belonging in a PostSocialist/War Milieu. Anthropological Notebooks, 21, 5-25.

Edensor, T., \& Holloway, J. (2008). Rythmanalysing the Coach Tour: The Ring of Kerry, Ireland. Transactions of the Institute of British Geographers, 33, 483-501. https://doi.org/10.1111/j.1475-5661.2008.00318.x

Edensor, T., \& Richards, S. (2007). Snowboarders vs Skiers: Contested Choreographies of 
the Slopes. Leisure Studies, 26, 97-114.

https://doi.org/10.1080/02614360500372224

Fabian, J. (1984). Time and the Other: How Anthropology Makes Its Object. New York, NY: Colombia University Press.

Faulconbridge, J., \& Hui, A. (2016). Traces of a Mobile Field: Ten Years of Mobilities Research. Mobilities, 11, 1-14. https://doi.org/10.1080/17450101.2015.1103534

Fincham, B., McGuiness, M., \& Murray, L. (2010). Mobile Methodologies. Basingstoke: Palgrave Macmillan. https://doi.org/10.1057/9780230281172

Fotsch, P. M. (2007). Watching Traffic Go By: Transportation and Isolation in Urban America. Arlington, TX: University of Texas Press.

Freund, P., \& Martin, G. (2007). Hyperautomobility, the Social Organization of Space, and Health. Mobilities, 2, 37-49. https://doi.org/10.1080/17450100601106237

Geurts, K. L. (2005). Consciousness as "Feeling in the Body": A West African Theory of Embodiment, Emotion and the Making of a Mind. In D. Howes (Ed.), Empire of the Senses: The Sensory Culture Reader (Sensory Formations) (pp. 164-178). Oxford: Berg.

Gilroy, P. (2001). Driving While Black. In D. Miller (Ed.), Car Cultures (pp. 133-152). Oxford: Berg.

Gorz, A. (1973). The Social Ideology of the Motorcar. Le Sauvage, September-October. http://www.worldcarfree.net/resources/freesources/TheSocialIdeology.rtf

Gupta, A., \& Ferguson, J. (1997). Anthropological Locations: Boundaries and Grounds of a Field Science. Berkeley, CA: University of California Press.

Hannam, K., Sheller, M., \& Urry, J. (2006). Editorial: Mobilities, Immobilities and Moorings. Mobilities, 1, 1-22. https://doi.org/10.1080/17450100500489189

Haraway, D. (1991). Simians, Cyborgs, and Women: The Reinvention of Nature. London: Free Association Books.

Horton, D., Rosen, P., \& Cox, P. (2007). Cycling and Society. Aldershot: Ashgate.

Howes, D. (1991). The Varieties of Sensory Experience: A Sourcebook in the Anthropology of the Senses. Toronto: University of Toronto Press.

Howes, D. (2005). Empire of the Senses. Oxford: Berg.

Huijbens, E. H. (2007). Practising Highland Heterotopias in the Interior of Iceland. Mobilities, 2, 143-165. https://doi.org/10.1080/17450100601106518

Hutch, R. (2007). Speed Masters Throttle Up: Space, Time and the Sacred Journeys of Recreational Motorcyclists. International Journal of Motorcycle Studies, 1-11. http://ijms.nova.edu/index.html

Idhe, D. (1974). The Experience of Technology: Human-Machine Relations. Cultural Hermeneutics, 2, 267-279.

Ingold, T., \& Vergunst, J. L. (2008). Ways of Walking: Ethnography and Practice on Foot. Aldershot: Ashgate.

Jain, J., \& Guiver, J. (2001). Turning the Car Inside Out: Transport, Equity and Environment. Social Policy and Administration, 35, 569-586. https://doi.org/10.1111/1467-9515.t01-1-00254

Katz, J. (2000). How Emotions Work. Chicago, IL: University of Chicago Press.

Kellner, D. (2000). Virilio, War and Technology: Some Critical Reflections. In J. Armitage (Ed.), Paul Virilio: From Modernism to Hypermodernism and Beyond (pp. 103-125). London: Sage Publishers. https://doi.org/10.4135/9781446218242.n6 
Klaeger, G. (2012). Rush and Relax: The Rythms and Speeds of Touting Perishable Products on a Ghanaian Roadside. Mobilities, 7, 537-554. https://doi.org/10.1080/17450101.2012.718936

Larkin, B. (2013). Signal and Noise: Media, Infrastructure, and Urban Culture in Nigeria. Durham, NC: Duke University Press. https://doi.org/10.1215/9780822389316

Latimer, J., \& Munro, R. (2006). Driving the Social. Sociological Review, 54, 32-53. https://doi.org/10.1111/j.1467-954x.2006.00636.x

Latour, B. (1996). On Actor Network Theory: A Few Clarifications. Soziale Welt, 47, 369-381.

Laurier, E. (2004). Doing Office Work on the Motorway. Theory, Culture and Society, 21, 261-277. https://doi.org/10.1177/0263276404046070

Laurier, E., Lorimer, H., Brown, B., Jones, O., Juhlin, O., Noble, A., Perry, M., Pica, D., Sormani, P., Strebel, I., Swann, L., Taylor, A. S., Watts, L., \& Weilman, A. (2008). Driving and "Passengering": Notes on the Ordinary Organization of Travel. Mobilities, 3, 1-23. https://doi.org/10.1080/17450100701797273

Lefebvre, H. (1971). Everyday Life in the Modern World. Rabinovitch, S., Trans., London: Allen Lane.

Lipset, D., \& Handler, R. (2014). Vehicles: Cars, Canoes, and Other Metaphors of Moral Imagination. Oxford: Berghahn.

Lofgren, O. (2008). Motion and Emotion: Learning to Be a Railway Traveller. Mobilities, 3, 331-351. https://doi.org/10.1080/17450100802376696

Marcus, G. E. (1995). Ethnography in/of the World System: The Emergence of MultiSited Ethnography. Annual Review of Anthropology, 24, 95-117.

https://doi.org/10.1146/annurev.an.24.100195.000523

Massumi, B. (2002). Parables for the Virtual: Movement, Affect, Sensation. Durham, NC: Duke University Press. https://doi.org/10.1215/9780822383574

Mauss, M. (1973). Techniques of the Body. Economy and Society, 2, 70-88. https://doi.org/10.1080/03085147300000003

Merriman, P. (2006). Mirror, Signal, Manoeuvre: Assembling and Governing the Motorway Driver in Late 1950s Britain. Sociological Review, 54, 75-92. https://doi.org/10.1111/j.1467-954x.2006.00638.x

Michael, M. (2000). Reconnecting Culture, Technology and Nature. London: Routledge.

Miller, D. (2001). Car Cultures. Oxford: Berg.

Morse, M. (1998). Virtualities: Television, Media Art and Cyberculture. Indiana: Indiana University Press.

Neumann, M. (1993). Living on Tortoise Time: Alternative Travel as the Pursuit of Lifestyle. Symbolic Interaction, 16, 201-235. https://doi.org/10.1525/si.1993.16.3.201

Paterson, M. (2007). Automobile Politics: Ecology and Cultural Political Economy. Cambridge: Cambridge University Press.

Pearce, L. (2000). Driving North/Driving South: Reflections upon the Spatial/Temporal Co-ordinates of "Home". In L. Pearce (Ed.), Devolving Identities: Feminist Readings in Home and Belonging (pp. 162-178). Aldershot: Ashgate.

Pinch, P., \& Reimer, S. (2012). Moto-Mobilities: Geographies of the Motorcycle and Motorcyclists. Mobilities, 7, 439-457. https://doi.org/10.1080/17450101.2012.659466

Pink, S. (2009). Doing Sensory Ethnography. London: Sage. 
https://doi.org/10.4135/9781446249383

Potter, C. (2008) Sense of Motion, Senses of Self: Becoming a Dancer. Ethnos: Journal of Anthropology, 73, 444-465. https://doi.org/10.1080/00141840802563915

Rapport, N. J., \& Dawson, A. (1998). Home and Movement: A Polemic. In N. J. Rapport, \& A. Dawson (Eds.), Migrants of Identity: Perception of Home in a World of Movement (pp. 8-16). Oxford and New York, NY: Berg.

Sheller, M. (2007). Bodies, Cybercars and the Mundane Incorporation of Automated Mobilities. Social and Cultural Geography, 8, 175-197. https://doi.org/10.1080/14649360701360063

Sheller, M. (2015). Aluminum Dreams: The Making of Light Modernity. Cambridge, MA: MIT Press.

Sheller, M., \& Urry. J. (2000). The City and the Car. International Journal of Urban and Regional Research, 24, 737-757. https://doi.org/10.1111/1468-2427.00276

Sheller, M., \& Urry. J. (2006). The New Mobilities Paradigm. Environment and Planning $A, 38,207-226$. https://doi.org/10.1068/a37268

Stoller, P. (1989). The Taste of Ethnographic Things: The Senses in Anthropology. Philadelphia, PA: University of Pennsylvania Press.

Urry, J. (2004). The System of Automobility. Theory, Culture and Society, 21, 81-100. https://doi.org/10.1177/0263276404046059

Urry, J. (2006). Inhabiting the Car. Sociological Review, 54, 17-31. https://doi.org/10.1111/j.1467-954x.2006.00635.x

Urry, J., \& Larsen, J. (1990). The Tourist Gaze. London: Sage.

Vannini, P. (2009). The Cultures of Alternative Mobilities: Routes Less Travelled. Farnham: Ashgate.

Vannini, P. (2010). Mobile Cultures: From the Sociology of Transportation to the Study of Mobilities. Sociology Compass, 4, 111-121. https://doi.org/10.1111/j.1751-9020.2009.00268.x

Virillo, P. (1986). Speed and Politics. New York, NY: Semiotext(e).

Virillo, P. (1997). Open Sky. London: Verso.

Waskul, D. D., \& Waskul, M. E. (2009). Paddle and Portage: The Travail of BWCA Canoe Travel. In P. Vannini (Ed.), The Cultures of Alternative Mobilities: Routes Less Travelled (pp. 21-37). Farnham: Ashgate.

Yazıc1, B. (2013). Towards an Anthropology of Traffic: A Ride through Class Hierarchies on Istanbul's Roadways. Ethnos: Journal of Anthropology, 78, 515-542.

https://doi.org/10.1080/00141844.2012.714395 
Submit or recommend next manuscript to SCIRP and we will provide best service for you:

Accepting pre-submission inquiries through Email, Facebook, LinkedIn, Twitter, etc. A wide selection of journals (inclusive of 9 subjects, more than 200 journals)

Providing 24-hour high-quality service

User-friendly online submission system

Fair and swift peer-review system

Efficient typesetting and proofreading procedure

Display of the result of downloads and visits, as well as the number of cited articles Maximum dissemination of your research work

Submit your manuscript at: http://papersubmission.scirp.org/

Or contact aa@scirp.org 